\title{
Variations in microbial density and in-situ water quality characteristics of cassava fermentation medium for fufu production
}

\begin{abstract}
Fermentation technology is as old as the history of man. Several foods are produced through fermentation technology. Fufu is produced from cassava through complete submerging of the cassava tuber in water to soften it, which is then sieved into slurry and dewater to some extent and cooked. This study investigated the variations in microbial density and in-situ water quality characteristics of cassava fermentation medium for fufu production. Triplicate samples of raw cassava tuber was obtained from a small-scale cassava processor in Ndemili, Delta state, Nigeria. The peeled cassava tuber was completely submerged in water for $0-144$ hours. At every 24 hours interval the water from the fermentation medium was analyzed for microbial density and in-situ $(\mathrm{pH}$, temperature, total dissolved solid, salinity, conductivity and turbidity) water quality. Results were in the range of $3.13-7.37 \mathrm{Log}$ $\mathrm{cfu} / \mathrm{ml}$ for total fungi counts, $6.08 \mathrm{Log} \mathrm{cfu} / \mathrm{ml}$ for total heterotrophic bacteria counts, $115.80-4347.33 \mathrm{mg} / \mathrm{l}$ for total dissolved solid, $165.90-10869.07 \mu \mathrm{S} / \mathrm{cm}$ for conductivity, $65.50-4347.33 \mathrm{ppm}$ for salinity and 33.80-602.67NTU for turbidity, which increased as fermentation progressed. The $\mathrm{pH}$ decreased (tending toward acidity) as the fermentation period increased with a value range of 4.67-6.40. Temperature ranged from $28.67-29.20^{\circ} \mathrm{C}$. There was significant variation $(p<0.05)$ between the various period of fermentation except for temperature. The findings of this study showed the variations that occurs during the fermentation of cassava tuber for $f u f u$ production.
\end{abstract}

Volume 4 Issue 6- 2018

\author{
Sylvester Chibueze Izah \\ Department of Biological Sciences, Niger Delta University, \\ Nigeria
}

Correspondence: Sylvester Chibueze Izah, Department of Biological Sciences, Faculty of Science, Niger Delta University, Wilberforce Island, Bayelsa state, Nigeria, Tel: +234 7030192 466,Email chivestizah@gmail.com

Received: October 08, 2018 | Published: November 23, 2018

Keywords: Fufu, In-situ water quality, microorganisms, fermentation dynamics

\section{Introduction}

Cassava is among the major staple food in the world especially in many developing nations in Africa. Cassava is a major source of dietary carbohydrate. In addition, it is a starchy crop that stores its food in the root. Cassava is produced in many countries in the world. A significant amount of global cassava tuber is produced in Africa. ${ }^{1,2}$ Nigeria is the largest cassava producing nation in the world accounting for over $20 \%$ of global production. ${ }^{1-18}$ In Africa, cassava is also produced in Ghana, Congo Democratic Republic, Angola among others. ${ }^{1}$ Cassava is also produced in large scale in other countries of the world including Thailand, Indonesia, Brazil, Vietnam and India. In Nigeria an appreciable quantity of cassava tuber produced is used to produce gari (cassava flake). Izah ${ }^{2}$ estimated that about $60 \%$ of total cassava produced is used for the production of gari in Nigeria. The cassava cultivation and processing is dominated by smallholders that occupy about $80 \%$ of the sector. Like gari, flour, fufu are produced from cassava tuber. Cassava is also used as active ingredients for the production of livestock feeds, confectionaries, sweeteners, adhesives, some pharmaceuticals. In addition cassava is used for the production of bioethanol and cassava-bread. In many part of the Niger Delta, fufu processing is a major source of livelihood to some families. Like many other food, fufu is sold in markets, streets etc. Fufu is produced from fermented cassava slurry. ${ }^{18,19}$ The fermentation process involves soaking (complete submerging) of the peeled cassava tuber in water. The fermentation period varies ranging from 4-7days depending on the variety, age and other environmental condition (such as temperature) of the fermentation medium. Sometimes, the cassava tuber is washed and fermented with their peel which is then removed after the process.
Within 2 days of fermentation, bubbles begin to develop at the top of the fermentation medium, and during the process the cassava tuber begins to be soft. Instances of cassava tuber not been completely soft after 5days of fermentation have been observed. As such, some fufu processors occasionally used hot water for fermentation process so as to facilitate transformation of the cassava to slurry. Typically, fermentation process is as old as human history. ${ }^{20,21}$ During fermentation process several biological, physical and chemical changes takes place. ${ }^{22-24}$ Studies have also indicated that microorganism play essential role in the fermentation processes. ${ }^{20}$ To this effects several microbes including Staphylococcus aureus, Escherichia coli, Enterobacter, Pseudomonas, Bacillus, Micrococcus species (bacteria), Aspergillus flavus, Aspergillus niger, Penicillium, Rhizopus, Mucor, Fusarium, Geotrichum species (Fungi) have been isolated from maize fermentation medium for pap "ogi" production..$^{23}$ Some of these microbes may be environmental contaminants that enter the medium through water and other materials used for the fermentation processes. Studies have shown the fermentation dynamics of in-situ and microbial density of maize ${ }^{22}$ and guinea corn. ${ }^{24,25}$ But information about the fermentation dynamics of cassava tuber used for fufu production is scanty in literature. Hence this study focused on in-situ water quality and microbial population of cassava fermentation medium for $f u f u$ production.

\section{Materials and methods}

\section{Field sampling}

The cassava tuber used for the study was obtained from a small- 
scale cassava processor in Ndemili, Delta state, Nigeria. The cassava was peeled and transported to the laboratory in a jute bag and it was used after 12 hours of harvesting from the plantation.

\section{Sample preparation}

The cassava samples was washed with borehole water and then cut into pieces using knife and submerged completely in a 4 liter container. The cap of the container was loosely covered. Then after, $2 \mathrm{ml}$ of the fermentation water was obtained at $0,24,48,72,96,120$ and 144hours for the enumeration of microbial density. Furthermore, the in-situ characteristics (temperature, $\mathrm{pH}$, conductivity, salinity and total dissolved solid) of the fermentation medium were determined by dipping the calibrated probe of the various water quality meters. Also $10 \mathrm{ml}$ of the fermentation water was collected for turbidity determination.

\section{In-situ analysis}

The in-situ characteristics analyzed in this study were carried out following manufactures guide. The $\mathrm{pH}$ was analyzed using $\mathrm{pH}$ meter (Extech DO700) following 3-point calibration $(7.00 \mathrm{pH}, 4.00 \mathrm{pH}$ and $10.01 \mathrm{pH})$. Total dissolved solid, conductivity, salinity and temperature of the medium was analyzed with a multipurpose meter (Extech EC400), while the turbidity was determined with turbidity meter (Extech Model TB400).

\section{Enumeration of microbial density}

Two media viz: Nutrient Agar (for total heterotrophic bacteria count) and Potato dextrose agar (for mould and yeast) were used in this study. Pour plate method previously described by Pepper and Gerba $^{25}$ and Benson ${ }^{26}$ were adopted in this study. The water from the fermentation medium during the interval of study was serial diluted, and $1 \mathrm{ml}$ was plated in sterile petri dish. Then after, prepared nutrient agar and potato dextrose agar was poured in the respective petri dish. The agar plate for total heterotrophic bacteria and total fungi was incubated for 24-48hours and 3-4 days respectively at room temperature. Then after, the colonies that grew on the various medium were counted and expressed as colony forming units (cfu) $/ \mathrm{ml}$ of the cassava fermentation water.

\section{Statistical analysis}

SPSS software version 20 was used to carry out the statistical analysis of logarithm transformed microbial counts and in-situ water quality parameter. Data obtained from the triplicate investigation were expressed as mean \pm standard deviation. Significance level at $\alpha=0.05$ was determined using one way analysis of variance. WallerDuncan statistics was used to compare means. Pearson's correlation matrix was used to show the relationship between the various insitu parameters. The chart for Microbial density was plotted with Paleontological statistics software package by Hammer et al. ${ }^{27}$

\section{Results and discussion}

The population of total fungi and total heterotrophic bacteria during cassava fermentation for $f u f u$ production is presented in Figure $1 \&$ Figure 2 respectively. The microbial counts were $4.13 \mathrm{Log} \mathrm{cfu} / \mathrm{ml}$ at 0 hours, $5.86 \mathrm{Log} \mathrm{cfu} / \mathrm{ml}$ at $72 \mathrm{hours}$ and $7.37 \mathrm{Log} \mathrm{cfu} / \mathrm{ml}$ at $144 \mathrm{hours}$ for total fungi (Figure 1), and 6.08Log cfu/ml at 0 hours, 8.39Log cfu/ $\mathrm{ml}$ at 72 hours and $11.28 \mathrm{Logcfu} / \mathrm{ml}$ at 144 hours for total heterotrophic bacteria counts (Figure 2). Significant variations $(p<0.05)$ exist among the various time interval. Typically as the fermentation proceeds the microbial density increased. As fermentation proceeds the physical and chemical characteristics of the medium are altered. Kigigha et al. ${ }^{17}$ reported that as fermentation continues the diversity of microbes' decreases and favour the proliferation of specific group of organisms. The trend of microbial density reported in this study is in consonance with the findings of Okowa et al. ${ }^{20}$ that reported an increase from $7.11 \mathrm{Log} \mathrm{cfu} / \mathrm{ml}$ at 0 hours to $11.17 \mathrm{Log} \mathrm{cfu} / \mathrm{ml}$ at 96 hours for total heterotrophic bacteria, and $4.16 \mathrm{Log} \mathrm{cfu} / \mathrm{ml}$ at 0 hours to $6.52 \mathrm{Log}$ $\mathrm{cfu} / \mathrm{ml}$ at 96 hours for yeasts/mould in maize fermentation medium. Kigigha and Kombo (2017) also reported that the density of total heterotrophic bacteria and total fungi increased from $4.62 \mathrm{Log} \mathrm{cfu} /$ $\mathrm{ml}$ at 0 hours to $6.85 \mathrm{Logcfu} / \mathrm{ml}$ at 72 hours and $3.78 \mathrm{Log} \mathrm{cfu} / \mathrm{ml}$ at 0hours to $4.71 \mathrm{Log} \mathrm{cfu} / \mathrm{ml}$ at $72 \mathrm{hours}$, respectively in a guinea corn fermentation medium. The variation could be due to difference in the biochemical characteristics of the substrates being fermented.

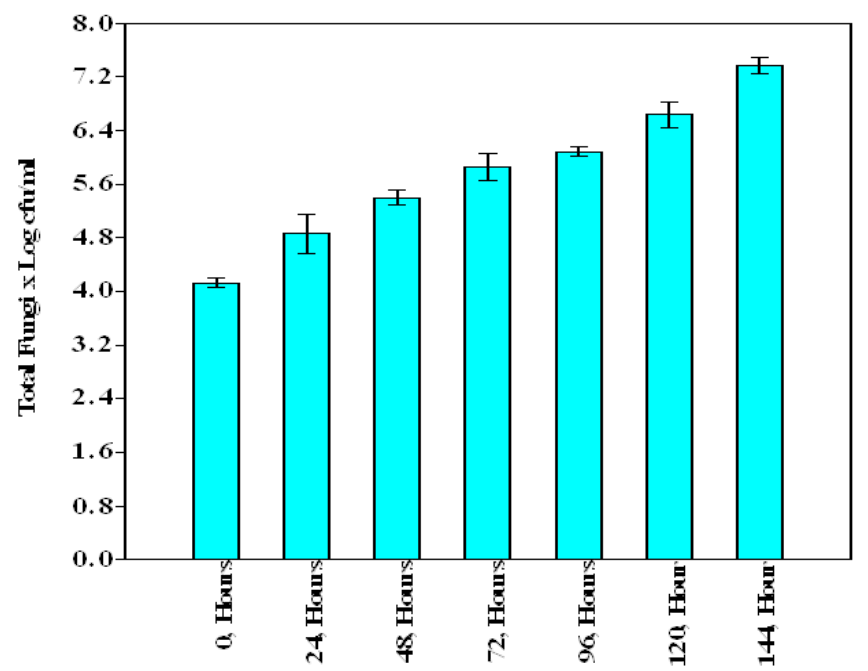

Figure I Density of total fungi during cassava fermentation for fufu production.

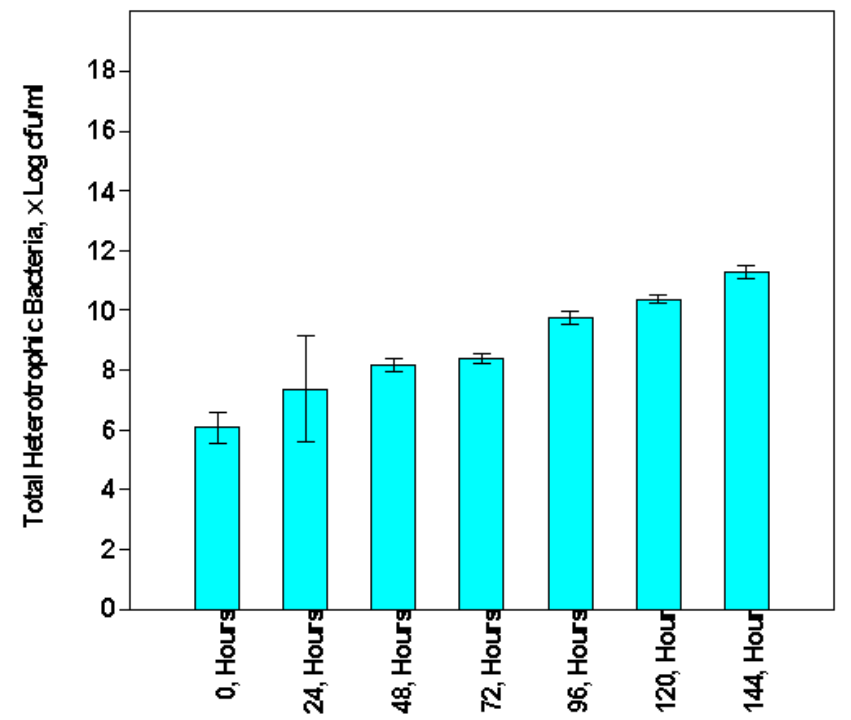

Figure 2 Population of total heterotrophic bacteria during cassava fermentation for fufu production. 
The in-situ characteristics of cassava fermentation medium for fufu production between 0-144hours is presented in Table 1, while the Pearson's correlation coefficient (r) matrix for the in-situ characteristics is presented in Table 2 . The values were $165.90 \mu \mathrm{S} /$ $\mathrm{cm}$ at 0 hours, $2361.00 \mu \mathrm{S} / \mathrm{cm}$ at 72 hours and $10869.07 \mu \mathrm{S} / \mathrm{cm}$ at 144hours for conductivity, $115.80 \mathrm{mg} / 1$ at 0 hours, $1652.40 \mathrm{mg} / 1$ at 72 hours and $4347.33 \mathrm{mg} / \mathrm{l}$ at 144 hours for total dissolved solid, 65.50 ppm at 0 hours, $944.30 \mathrm{ppm}$ at 72 hours and $4347.33 \mathrm{ppm}$ at 144 hours for salinity, 33.80NTU at 0 hours, $312.67 \mathrm{NTU}$ at 72 hours and $602.67 \mathrm{NTU}$ at 144 hours for turbidity, 6.40 at 0 hours, 5.46 at 72 hours and 4.67 at 144 hours for $\mathrm{pH}$. There was significant $(\mathrm{p}<0.05)$ increase in conductivity, salinity, total dissolved solid, turbidity and decline $\mathrm{pH}$ as the fermentation period increased. Temperature during the fermentation period $(0-144$ hours $)$ ranged from $28.67-29.20^{\circ} \mathrm{C}$, being not significantly $(\mathrm{p}>0.05)$ different among the various period of fermentation. The increased in conductivity, salinity and total dissolved solid may be due the effect of the microbial consortia in the fermentation medium. Also the increase in these parameters also suggests that ions in the water have increased. As the fermentation medium continues the turbidity level increased due to microbial growth and changes in physical and chemical characteristics of the fermentation medium. This may have caused the medium to be become more acidic. Typically, cassava is acidic in nature and during its processing into gari, the effluents generated have been reported to be acidic. ${ }^{7,13}$ Conductivity showed positive significant relationship with salinity, total dissolved solid and turbidity and negatively correlate with $\mathrm{pH}$ at $\mathrm{p}<0.01$. Total dissolved solid showed positive significant correlation with salinity and turbidity and negatively correlate with $\mathrm{pH}$ at $\mathrm{p}<0.01$. Salinity positively correlates with turbidity and negatively correlate with $\mathrm{pH}$ at $\mathrm{p}<0.01$, and turbidity negatively correlate with $\mathrm{pH}$ at $\mathrm{p}<0.01$ (Table 2). The significant relationship between conductivity, salinity and total dissolved solid suggest that they mutually dependent.

Table 1 In-situ water quality parameter during cassava fermentation for fufu production

\begin{tabular}{lllllll}
\hline $\begin{array}{l}\text { Fermentation } \\
\text { period, Hours }\end{array}$ & Conductivity, $\mu \mathrm{S} / \mathrm{cm}$ & $\begin{array}{l}\text { Total dissolved } \\
\text { solid, } \mathrm{mg} / \mathrm{l}\end{array}$ & Salinity, ppm & Turbidity, NTU & $\mathrm{pH}$ & $\begin{array}{l}\text { Temperature, } \\
{ }^{\circ} \mathrm{C}\end{array}$ \\
\hline .00 & $165.90 \pm 5.57 \mathrm{a}$ & $115.80 \pm 3.40 \mathrm{a}$ & $65.50 \pm 1.97 \mathrm{a}$ & $33.80 \pm 6.58 \mathrm{a}$ & $6.40 \pm 0.02 \mathrm{e}$ & $28.77 \pm 0.65 \mathrm{a}$ \\
24.00 & $704.03 \pm 4.43 \mathrm{~b}$ & $491.93 \pm 2.74 \mathrm{~b}$ & $280.97 \pm 1.25 \mathrm{~b}$ & $87.63 \pm 5.03 \mathrm{~b}$ & $6.19 \pm 0.02 \mathrm{de}$ & $28.70 \pm 0.44 \mathrm{a}$ \\
48.00 & $1601.90 \pm 9.06 \mathrm{c}$ & $1121.43 \pm 7.00 \mathrm{c}$ & $640.77 \pm 4.48 \mathrm{c}$ & $181.93 \pm 9.45 \mathrm{c}$ & $5.99 \pm 0.03 \mathrm{~d}$ & $29.20 \pm 0.30 \mathrm{a}$ \\
72.00 & $2361.00 \pm 26.46 \mathrm{~d}$ & $1652.40 \pm 18.28 \mathrm{~d}$ & $944.30 \pm 10.44 \mathrm{~d}$ & $312.67 \pm 11.57 \mathrm{~d}$ & $5.46 \pm 0.13 \mathrm{c}$ & $28.90 \pm 0.78 \mathrm{a}$ \\
96.00 & $3060.37 \pm 37.83 \mathrm{e}$ & $2141.77 \pm 27.08 \mathrm{e}$ & $1224.03 \pm 14.56 \mathrm{e}$ & $361.33 \pm 44.42 \mathrm{e}$ & $5.11 \pm 0.04 \mathrm{~b}$ & $28.97 \pm 0.89 \mathrm{a}$ \\
120.00 & $5322.07 \pm 91.08 \mathrm{f}$ & $2127.77 \pm 34.15 \mathrm{e}$ & $2127.77 \pm 34.15 \mathrm{f}$ & $525.13 \pm 26.00 \mathrm{f}$ & $4.87 \pm 0.15 \mathrm{ab}$ & $28.83 \pm 0.35 \mathrm{a}$ \\
144.00 & $10869.07 \pm 391.00 \mathrm{~g}$ & $4347.33 \pm 156.7 \mathrm{If}$ & $4347.33 \pm 156.7 \mathrm{~g}$ & $602.67 \pm 26.50 \mathrm{~g}$ & $4.67 \pm 0.25 \mathrm{a}$ & $28.67 \pm 0.32 \mathrm{a}$ \\
\hline
\end{tabular}

Each value is expressed as mean \pm standard deviation $(n=3)$; Different alphabets along the column indicate significant variation $(\mathrm{P}<0.05)$ according to WallerDuncan Statistics

Table 2 Pearson's correlation matrix of the in-situ water quality parameter during cassava tuber fermentation for fufu production

\begin{tabular}{lllllll}
\hline Parameters & Conductivity & TDS & Salinity & Turbidity & $\mathrm{pH}$ & Temperature \\
Conductivity & $\mathrm{I}$ & & & & \\
\hline TDS & $0.968^{* *}$ & $\mathrm{I}$ & & & \\
Salinity & $1.000^{* *}$ & $0.968^{* *}$ & $\mathrm{I}$ & & \\
Turbidity & $0.904^{* *}$ & $0.926^{* *}$ & $0.904^{* *}$ & $\mathrm{I}$ & \\
$\mathrm{pH}$ & $-0.847^{* *}$ & $-0.900^{* *}$ & $-0.847^{* *}$ & $-0.967^{* *}$ & $\mathrm{I}$ & \\
Temperature & -0.140 & -0.084 & -.141 & -0.033 & 0.103 & $\mathrm{I}$ \\
\hline
\end{tabular}

**. Correlation is significant at the 0.01 level (2-tailed). $\mathrm{N}=21$

The trend reported in this study has been reported in related studies. For instance, Kigigha and $\mathrm{Kombo}^{24}$ reported that salinity, conductivity, total dissolve solid and turbidity increased and $\mathrm{pH}$ decreased as guinea corn fermentation period increased. The authors reported a value of $99.10 \mathrm{ppm}$ at 0 hours to $966.53 \mathrm{ppm}$ at $72 \mathrm{hours}$ for salinity, $211.50 \mu \mathrm{S} / \mathrm{cm}$ at 0 hours to $1585.13 \mu \mathrm{S} / \mathrm{cm}$ at 72 hours for conductivity, $107.53 \mathrm{mg} / \mathrm{l}$ at 0 hours to $1320.22 \mathrm{mg} / \mathrm{l}$ at 72 hours for total dissolved solid and 59.63 NTU at 0 hours to $356.30 \mathrm{NTU}$ at 72 hours for turbidity, and $\mathrm{pH}$ decreased from 6.40 at 0hours to 3.98 at 72 hours. Okowa et al. ${ }^{22}$ also reported that as maize fermentation period increased the in-situ parameters increased from $114.67 \mathrm{ppm}$ at 0 hours to $1663.33 \mathrm{ppm}$ at 96 hours for salinity, $230.00 \mu \mathrm{S} / \mathrm{cm}$ at 0 hours to $2903.33 \mu \mathrm{S} / \mathrm{cm}$ at 96 hours for conductivity, $161.33 \mathrm{mg} / 1$ at 0 hours to $2076.73 \mathrm{mg} / 1$ at 96 hours for total dissolved solid and $65.17 \mathrm{NTU}$ at 0 hours to $473.33 \mathrm{NTU}$ at 96 hours for turbidity, and $\mathrm{pH}$ decreased from 6.37 at 0 hours to 3.83 hours at 96 hours, and temperature fluctuates between $28.47-29.57^{\circ} \mathrm{C}$. Again, the variation in the values could be due to the biochemical characteristics of the substrates.

\section{Conclusion}

Microorganisms play essential role during the fermentation of cassava tuber for $f u f u$ production. They are vital in determining 
the quality of a specific food. Throughout human history several food products have been produced through fermentation. Fufu is commonly produced and consumed in many areas in Nigeria. During fermentation of the cassava tuber for slurry preparation several physical, chemical and microbiological activities take place. This study investigated the changes in microbial density and in-situ water quality characteristics during fermentation of cassava tuber for fufu production. The study showed an increased microbial population (total heterotrophic bacteria and total fungi) and in-situ water quality (viz: salinity, conductivity, total dissolved and turbidity, and a decline in $\mathrm{pH}$ (tending toward acidity).

\section{Acknowledgments}

None.

\section{Conflicts of interest}

The author(s) declares that there is no conflicts of interest.

\section{References}

1. Izah SC, Bassey SE, Ohimain EI. Impacts of Cassava mill effleunts in Nigeria. Journal of Plant and Animal Ecology. 2018; 1(1):14- 42

2. Izah SC. Estimation of Potential Cassava Mill Effluents Discharged into Nigerian Environment. Environmental Analysis and Ecology Studies. 2018;2(5):EAES.000550.

3. Izah SC, Bassey SE, Ohimain EI. Ecological risk assessment of heavy metals in cassava mill effluents contaminated soil in a rural community in the Niger Delta Region of Nigeria. Molecular Soil Biology. 2018; 9(1):1-11.

4. Izah SC, Bassey SE, Ohimain EI. Assessment of heavy metal in cassava mill effluent contaminated soil in a rural community in the Niger Delta region of Nigeria. EC Pharmacology and Toxicology. 2017;4(5):186-201.

5. Izah SC, Bassey SE, Ohimain EI. Geo-accumulation index, enrichment factor and quantification of contamination of heavy metals in soil receiving cassava mill effluents in a rural community in the Niger Delta region of Nigeria. Molecular Soil Biology. 2017;8(2):7-20.

6. Izah SC, Bassey SE, Ohimain EI. Assessment of pollution load indices of heavy metals in cassava mill effluents contaminated soil: a case study of small-scale cassava processing mills in a rural community of the Niger Delta region of Nigeria. Bioscience Methods. 2017;8(1):117.

7. Izah SC, Bassey SE, Ohimain EI. Changes in the treatment of some physico-chemical properties of cassava mill effluents using Saccharomyces cerevisiae. Toxics. 2017;5(4):28.

8. Izah SC, Bassey SE, Ohimain EI. Removal of Heavy Metals in Cassava Mill Effluents with Saccharomyces cerevisiae isolated from Palm Wine. MOJ Toxicology. 2017;3(4):00057.

9. Izah SC, Bassey SE, Ohimain EI. Cyanide and Macro-Nutrients Content of Saccharomyces cerevisiae Biomass Cultured in Cassava Mill Effluents. International Journal of Microbiology and Biotechnology. 2017;2(4):176-180.

10. Izah SC, Bassey SE, Ohimain EI. Amino acid and proximate composition of Saccharomyces cerevisiae biomass cultivated in Cassava mill effluents. Molecular Microbiology Research. 2017;7(3):20-29
11. Izah SC, Bassey SE, Ohimain EI. Assessment of Some Selected Heavy Metals in Saccharomyces cerevisiae Biomass Produced from Cassava Mill Effluents. EC Microbiology. 2017;12(5):213-223.

12. Izah SC, Aigberua AO. Assessment of Microbial Quality of Cassava Mill Effluents Contaminated Soil in a Rural Community in the Niger Delta, Nigeria. EC Microbiology. 2017;13(4):132-140.

13. Izah SC, Ohimain EI. Bioethanol production from cassava mill effluents supplemented with solid agricultural residues using bakers' yeast [Saccharomyces cerevisiae]. Journal of Environmental Treatment Techniques. 2015;3(1):47-54.

14. Izah SC. Estimation of Saccharomyces cerevisiae Biomass Cultured in Cassava Mill Effluents. Environmental Analysis and Ecology Studies. 2018;2(5):EAES.000547.

15. Izah SC. Growth Pattern of Saccharomyces cerevisiae in Cassava Mill Effluents. Journal of plant and Animal Ecology. 2018;1(2):10- 15.

16. Izah SC. Feed potentials of Saccharomyces cerevisiae biomass cultivated in palm and cassava mill effluents. Journal of Bacteriology and Mycology. 2018;6(5):00220.

17. Kigigha LT, Nyenke P, Izah SC. Health risk assessment of selected heavy metals in gari (cassava flake) sold in some major markets in Yenagoa metropolis, Nigeria. MOJ Toxicol. 2018;4(2):47-52.

18. Kigigha LT, Izah SC, Kpea TB. Microbiological quality of fermented Cassava Flakes (Gari) sold in Yenagoa, Metropolis, Nigeria. Bulletin of Advanced Scientific Research. 2015;01(07):157-160.

19. Oduah NO, Adepoju PA, Longe O, et al. Effects Of Fermentation On The Quality And Composition Of Cassava Mash (Gari). International Journal of Food Nutrition and Safety. 2015;6(1):30-41.

20. Izah SC, Kigigha LT, Okowa IP. Microbial quality assessment of fermented maize Ogi (a cereal product) and options for overcoming constraints in production. Biotechnological Research. 2016;2(2):8193.

21. Ijabadeniyi AO. Microorganisms associated with ogi traditionally produced from three varieties of maize. Research Journal of Microbiology. 2007;2(3):247-253

22. Okowa IP, Kigigha LT, Izah SC. Variation in physicochemical water quality parameters during fermentation of maize for Ogi production. Biotechnological Research. 2016;2(3):125-131.

23. Kigigha LT, Izah, SC, Okowa IP. Microbial Characterization of Maize Fermentation Water during Ogi Production. Journal of Environmental Treatment Techniques. 2016;4(2):41-45.

24. Kigigha LT, Kombo N. Changes in microbial density and in-situwater quality parameters during fermentation of guinea corn (Sorghum bicolor) medium. ASIO Journal of Microbiology, Food Science \& Biotechnological Innovations. 2017;3(1):17-21.

25. Pepper IL, Gerba CP. Environmental microbiology. A laboratory manual. Second edition. Elsevier academic press, 2005.

26. Benson HJ. Microbiological Applications: Laboratory Manual in General Microbiology. complete version, 5th edition. New York: McGaraw-Hill; 2002.

27. Hammero, Harper DAT, Ryan PD. PAST: Paleontological statistics software package for education and data analysis. Palaeontologia Electronica. 2001;4(1):9. 